Faria, M. D., Silva, J. F. \& Ferreira, J. B. (2017). Transformative consumer research and the visually impaired: A study on restaurant services. Consumer Behavior Review, 1(Special

ISSN: 2526-7884

Editor: Prof. Dr. Marconi Freitas da Costa Email da revista: cbr@ufpe.br
Avaliação: Double blind review

Recebido: 16 de junho de 2017

Aceito: 08 de setembro de 2017

\title{
TRANSFORMATIVE CONSUMER RESEARCH AND THE VISUALLY IMPAIRED: A STUDY ON RESTAURANT SERVICES
}

\author{
Marina Dias de Faria \\ Jorge Ferreira da Silva \\ Jorge Brantes Ferreira
}

\begin{abstract}
Marina Dias de Faria is Professor of Marketing at Universidade Federal do Estado do Rio de Janeiro - UNIRIO. E-mail: marinafaria86@hotmail.com

Jorge Ferreira da Silva is Professor of Marketing at Pontifícia Universidade Católica do Rio de Janeiro - PUC-RIO. E-mail: shoshop@iaog.puc-ri.br

Jorge Brantes Ferreira is Professor of Marketing at Pontifícia Universidade Católica do Rio de Janeiro - PUC-RIO. Email: jorgebf@gmail.com

The authors thank the reviewers for the comments for improving the article.
\end{abstract}

\begin{abstract}
Citizens with disabilities wish and have the right to fulfill all social roles, including the consumer role. Business practitioners and scholars, however, frequently fail to consider these potential consumers. This study aims to analyze if the attributes the visually impaired most value in leisure services and environments are present in restaurants in Rio de Janeiro. Results point to certain fundamental attributes as being valued by people with low or no visual acuity in leisure restaurant outings: menus in Braille; personnel trained to serve ; tables with legs on each of its four corners and without sharp edges; low sound and light intensity; attendant paging devices; and adequate restroom facilities. Observations and interviews show that most restaurants have accessibility issues. Practical and social implications point to mandatory investments in infrastructure and personnel training in order to tend to the needs of the visually impaired according to legal and market requirements.

Keywords: Visually impaired, Restaurants, Transformative consumer research.
\end{abstract}




\section{INTRODUCTION}

Internationally, albeit rare, it is possible to find studies regarding people with disabilities as representatives of anunder-developed consumer market, evidencing an extant academic concern with the subject (Beudaert, Özçağlar-Toulouse, \& Türe, 2015, Goodrichk, \& Ramsey 2012; Van Harten, Veldhuis, Hoeksme, \& Krabbendam, 2007). In a direction counter to inclusion, there still reigns a certain disbelief regarding PWDs' potential as customers able to generate profits for companies (Baker et al, 2007), and this disbelief has proven stubborn to overcome.

People with disabilities (PWDs) account for $23,9 \%$ of the Brazilian population, which corresponds to more than 45 million people possessing physical, sensorial, mental, or multiple disabilities. Among those, almost 16 million have severe disabilities (IBGE 2010). Despite that, Brazilian researchers and practitioners seem to ignore this legion of consumers.

Regarding marketing research, the Transformative Consumer Research (TCR) perspective seems to broaden impaired consumer study venues. Mick (2006) considers TCR the first step in developing consumer behavior studies that focus on the benefits and well-being of people instead of enterprises. The author attempts to contextualize the importance of TCR using PWDs studies as examples.

Ozanne and Deschenes (2007) believe that research efforts classified as TCR by their authors do not emphasize enough the practical implications that studies classified as such should have. In a recent study, Ozanne (2011) renews the call for research efforts based on TCR that were indeed seeking actual improvement of consumers' realities. In an attempt to answer that call, the main objective of this study is to analyze the wishes of the visually impaired with regard to restaurant services in their leisure outings in the city of Rio de Janeiro. In order to achieve its main objective, this research also sought to identify which are the most important service and environment attributes for the visually impaired when it comes to the consumption experience in restaurants.The research problem explored here arises in a scenario of few studies that place the disabled person in the role of consumers. One of the main reasons for this configuration is the search for financial justification to carry out studies in marketing. Transformative research is extremely important for marketing studies to find relevance in improving the lives of consumers. It is important to emphasize that the recent Transformative Service Research (TSR) is perfectly in line with the proposal of this research. TSR's focus on eudaimonic and hedonic well-being outcomes (Kuppelwieser, \&Finsterwalder, 2016).

This study contributes to a better understanding of PWDs as consumers, focusing on a segment poorly explored by Brazilian marketing research. For practitioners, relevance resides in the offer of essential information regarding the needs and desires of potential restaurant customers (Faria, Silva, \& Ferreira 2012; Hogg, \& Wilson 2004), indicating also that modifications to the marketing mix in order to serve PWDs also appear to please those consumers without impairments (Gava, 2006). Poria, Reichel, and Brandt (2011), and Shi, Cole, and Chancellor (2012) deem essential for academics and practitioners to comprehend how PWDs understand and react to services and environments in order to minimize consumption barriers.

This study opted to direct its focus towards the visually impaired due to the preliminary literature review and interactions with professionals from organizations dedicated to work with PWDs. These professionals pointed out that organizations and businesses exhibit a particular lack of interest and action in fulfilling the specific needs of people with visual impairments when compared to the efforts made to cater to other PWDs. Extant literature supports this choice, arguing that the visually impaired are rarely studied in academic research concerning people with disabilities (Amaro, Camargo, \& Slongo, 2008). In addition, according to IBGE (2010), visual impairment is the most frequent disability among PWDs population in Brazil.

It is important to point that this study focused only on the instances in which PWDs sought restaurant services for leisure purposes. This is a necessary delimitation because previous studies show that, depending on the motivation behind an outing, different 
attributes are considered and evaluated (Koo, Tao, \& Yeung 1999). Extant research supports the importance of leisure activities in promoting social inclusion (Sassaki 2003; Shi, Collle, \& Chancellor 2012), while restaurants, being a social space where different lifestyles are represented alongside their innumerous social, cultural and symbolic implications, are an important service environment (Ipiranga, 2010).

\section{LITERATURE REVIEW}

\section{The Market Segment Formed by People with Disabilities}

Health professionals point to the fact that the numbers of PWDs around the globe tend to increase given the technological advances in medical practices. Many people who would have died in the past are now being saved albeit presenting irreversible sequelae (Baker, Holland, \& Kaufman-Scarborough, 2007).

PWDs, just like everybody else, have needs that can only be exercised and fulfilled via consumption (Ruddell, \& Shinew 2006). However, marketers seem to be unable to see PWDs as potential consumers (Faria, Silva, \& Ferreira 2012). Lack of interest and knowledge make the general population, along with managers and business agents, ignorant of PWDs' actual needs and demands (Sansivieiro, \& Dias 2005). Usually this fact reflects on the services provided, as exemplified by the absence of personnel trained to serve clients with disabilities (Hogg \& Wilson 2004).

According to Goodrich and Ramsey (2012), one of the main reasons for not tending to PWDs's consumption needs reside in the notion, shared by most services providers, that accessibility is a matter of reaction when a problem occurs, instead of envisioning PWDs' needs and demands just like the ones coming from other consumers. Lukaszewski and Stone (2012) suggest that more academic research efforts concerned with the interaction between service providers and PWDs are needed.

Predicaments routinely faced by PWDs are plenty, some professional, some personal. Among common barriers found on a daily basis are: steps, stairs, sidewalks, lack of subtitles and sign language in featured movies and TV programs, and limitations related to public transport (David, Gurgel, Antunes, \& Kastrup,
2009). Those barriers hinder, or even prevent, PWDs from exercising some social roles, including the one of consumer. Hogg and Wilson (2004) consider that, in a society where consumption practices contribute to the formation of individuals' identities, the excessive hindrances imposed on PWDs' consumption processes may cause them severe identity issues.

Brazilian laws envision PWDs inclusion in consumption practices, regulating priority in serving PWDs and establishing general rules for accessibility. Brazil, however, is far from offering ideal conditions for PWDs in their pursuit of consumption practices (Faria, Casotti \& Carvalho, 2016).

Baker, Stephens and Hill (2002) state that PWDs inclusion as consumers will only occur when they voice what adaptations must be implemented to services and goods. KaufmanScarborough (1999) supports this view by pointing that many of the imposed rules and norms do not match what PWDs consider important. Likewise, Prideaux and Roulstone (2009) point that legislation change must take place before factual accessibility.

\section{Visually Impaired Consumers}

There are around 6.5 million PWDs with visual impairments in Brazil. Visual impairment is defined by total or partial loss of visual perception. Among blind people, subject of this study, there are those who have lost their vision and those who were born blind (Poyares, \& Goldfeld, 2008). Visually impaired people tend to better develop other senses, such as hearing, which become fundamental in their communication and interaction processes (Dias, \& Pereira, 2008).

According to Sassaki (2003), accessibility barriers in retailing can be divided in attitudinal, communicative and architectonic. The first two arise from lack of personnel training, while the last encompasses all sort of structural issues.

Baker (2006) and Baker, Stephens and Hill (2002) demonstrate that, for the visually impaired, quality services suited to their needs are essential and often absent. Amaro et al. (2008) and Dias and Pereira (2008) alert that visually impaired people prefer environments without music and with low noise levels. 
Crowded environments are also inadequate due to cognitive differences in spatial perception and movement (David et al., 2009).

Paying for services is also a source of anxiety because they can't see the bills used in the exchange or values printed on the check or credit card slips (Amaro et al. 2008). Another common hindrance is the animal ban encompassing several environments, which affects guide dog owners. Within this context, it is clear that several aspects of restaurant and other services must be modified to become adequate for visually impaired consumer. Woodliffe (2004) points to the necessity of presenting visually impaired consumers with an array of different offers instead of a standardized one.

\section{Consumption in Restaurants During Leisure Outings}

As more people eat frequently out, economic and social significance of restaurants increases, making these establishments important for marketing research (Salazar, Farias, \& Lucian, 2009).

Several drives lead people to restaurants, from family celebrations to simple convenience (Pedraja \& Yagüe 2001). Eating out involves objective and tangible benefits. However, this choice of consumption also involves subjective, hedonic and symbolic components (Hirschman \& Holbrook 1982). For Chang and Hsieh (2006), eating in restaurants involves issues of selfidentity, since the type of restaurant one chooses says something about who one is or how one wants to be seen by others. Ryu et al. (2010) show that the choice of casual, fast-food restaurants by American consumers involves meeting both hedonic and utilitarian needs, while Salazar, Farias and Lucian (2009) defend that restaurant choice in leisure outings involves mostly hedonic needs and, often, the presence of friends. For Thompson (2011), in this context, kinship and group size greatly affect consumer behavior.

Depending on the particular drive that leads an individual to visit a restaurant, the most important factors in the decision of the consumer may vary. In celebrations and business functions, quality and type of food seem to be essential; location becomes a crucial factor when convenience is the chief motive, and the prestige of the restaurant appears to be important on leisure outings and business meetings. Independent of occasion, ambience is, most of the time, the main factor when choosing a restaurant (Salazar, Farias, \& Lucian, 2009). Pohl, Bollini and Fajardo (2009) demonstrate that the perceived importance of the atmosphere and ambience in the symbolic construction of consumers' assessment of a restaurant can, in some cases, outweigh the importance attached to the food itself. Griffith and Gilly (2012) support this view showing how little changes in atmosphere and ambience can increase restaurant profit. However, Kivela (1997) argues, based on research conducted in Hong Kong, that the quality and type of food are the most important variables in choosing a restaurant, regardless of the motive that led the consumer to seek out the establishment.

Consumers often link a full house with appetizing food, low prices and good reputation. On the other hand, crowded restaurants are viewed as offering poor service (Tse, Sin, \& Yin, 2002; Babin, Lee, Kim, \& Griffim, 2005).

Many restaurants are not prepared to serve consumers with special needs, such as elders (Grougiou, \& Pettigrew 2011). Moschis, Curasi and Bellenger (2003) indicate that elderly people value comfortable environments, discounts and convenience. Regarding Brazilian PWDs, a 2002 law states that hotels, restaurants and bars must offer Braille menus for visually impaired costumers. Rio de Janeiro's congress published a booklet with accessibility guidelines in 2005 that highlights the importance of restaurants having personnel and structures adapted to serve PWDs' needs (ALERJ, 2005).

\section{METHOD}

Deschenes (2007) shows that qualitative methods seem to be adequate to studies associated with TCR. The author points out that, for TCR studies, interaction between researcher and subject is crucial. Ozanne, Saatcioglu e Corus (2007) state that, as in action research, TCR studies should focus on improving subject's welfare. This research uses qualitative methods and attempts to keep strong interaction between researchers and subjects during the whole process. Empirical data were collected through multiple methods, thus offering a 
broader view of the phenomenon (Creswell, 1998).

Starting with three focus groups, the first step was to identify the attributes most valued by the visually impaired in a restaurant leisure outing. The second step involved observations and interviews taken inside restaurants in Rio de Janeiro, aiming to verify if the attributes identified as most relevant were present in the establishments.

For Turmusani (2004), research with the objective of understanding what is important regarding products or services must apply methods that entail direct contact between researcher and subject. White (2002) believes that an aspect that makes this personal contact so vital is the need for study validation from the subjects' perspective. During the conception of this study, the opinions of visually impaired members and employees of the organization "Centro de Vida Independente" (Center for an Independent Life) - institution that works to increase accessibility and PWDs inclusion in society -were listened. These individuals have supported the relevance of this study and pointed towards the adequacy of a particular focus on restaurants.

\section{Subject Selection}

Focal group subjects were selected among visually impaired residents in Rio de Janeiro who attend restaurants in leisure outings. Twenty-one visually impaired subjects were selected and divided in three different focus group sessions: seven for the first session, eight for the second and six for the third. This number of participants is considered adequate according to Prince and Davies (2001).

Braithwait and Thompson (2000) alert that stereotyped characterization of PWDs by academics may provoke negative responses to new research attempts, since PWDs resist being stereotyped and refuse to participate. Many of the contacted individuals refused to participate alleging that they have got tired of participating in interviews which yielded no practical result afterwards. During the realization of this study, there was an effort to clarify to subjects that, albeit academic research itself can't change reality, it can point out new ways by which transformation could be achieved.
Yin (2005) and Helgeson (1994) recommend gathering evidence from nine to twelve different cases, in order to visualize patterns in the phenomenon. Thus, twelve different restaurants were visited and analyzed. Differences between the restaurants regarding market segmentation, menu presentation, service and meals served were noted down. Two of the selected establishments were included because focus group results pointed them to be respectively the best and the worst restaurants in Rio de Janeiro.

The restaurants, identified by their initials, are: a traditional tea house (CC); an internationally famous steakhouse (PC); a high quality pizza parlor (EZ); a casual diner restaurant from a famous American restaurant chain (OB); a traditional Portuguese food restaurant (MJ); a Japanese restaurant placed in a traditional shopping mall $(\mathrm{SH})$; a vegetarian restaurant located at the most exclusive neighborhood in the city (VC); an all you can eat pizza parlor (PM); a restaurant close to the Benjamin Constant institute - national reference for visual impairment - (GU); an Arabian restaurant frequently present in gourmet food guides (AR); an Italian restaurant located in a high end shopping mall (OL); and a pizza parlor located in a luxury mall (RS).

\section{Data collection}

For Stokes and Bergin (2006), focus groups can lead to relevant results in Marketing research. The purpose of a data collection via focus groups is to use a group discussion to assess perspectives subjects weren't previously concerned with or prepared to articulate (Bill, \& Olaison 2009).

Concerning the ideal number of focus groups to participate in a given research, Boddy (2005) suggests between three to five or to keep going until the moderator can anticipate what will be discussed on the following group. This study reached saturation on the third group. Interactions between group participants were registered in audio and lately transcribed (Hunter, 2002). Group sessions took place at the houses of different participants, since most subjects did not feel comfortable to go to distant or unfamiliar locations given their visual impairments. 
The same script was followed for the three focus groups. First, the participants spoke about their personal characteristics. Secondly, a moderator asked them about their consumption habits in general. Then, there was a discussion regarding their consumption behavior and experiences in restaurants during leisure outings.

During restaurant visitation, data were collected by interviews and simple structured observation, a technique in which the researcher specifies what she wishes to observe and how it will be recorded (Laville, \& Dionne, 1999). The main focus of the observation was the accessibility attributes pointed as the most crucial by the focus groups.

Considering that observations alone could not identify all relevant attributes, researchers conducted complementary semi-structured interviews (Patton, 2002) with restaurant managers and waiters. In addition, to simulate an actual situation, in order to assess spontaneous responses, they also employed covert observation via a question presenting a hypothetical situation: "I'd like to bring a group of visually impaired people to this restaurant. Could we talk a bit about that?"

All interviews started with this question. Following it, came questions regarding infrastructure and service. All interviews were immediately registered in a journal to avoid the loss of any details. In the transcriptions, next to establishment initials, are the interviewees' occupations instead of their names, thus preserving their privacy.

\section{Data Treatment}

First, researchers transcribed all the audio recorded during focus group sessions (Boddy, 2005). The next step involved the application of classical content analysis to the transcriptions (Bauer, 2002), in order to identify which attributes were relevant to the visually impaired during their restaurant consumption experience.

In relation tothe data collected in restaurants via observation and interviews, treatment involved the transformation of the data collected by observation into descriptive information (Creswell, 1998) and the analysis of the interviews. The use of classical content analysis (Bauer, 2002; Sampieri, Collado, \&
Lucio, 2006), followed three main proceedings: (1) critical reading; (2) classical content analysis; and (3) categorization of terms and ideas (Hunter 2002).

\section{Limitations}

In addition to these, since this study employed focus group discussions, it is important to point out that participants may influence each other and goad the group towards a false sense of unanimity (Bill, \& Olaison, 2009), thus masquerading individual opinions and lowering the overall quality of the collected data.

Data collection also presented its limitations. All visited restaurants were located in affluent neighborhoods of Rio de Janeiro. Thus, it is safe to say that the sample of restaurants that the study considered does not represent well restaurants in other areas of Rio. Furthermore, it is possible to presume that restaurants located in the wealthiest part of the city would exhibit greater preoccupation with accessibility. Moreover, if these restaurants are not particularly accessible, it would be reasonable to posit that restaurants in Rio de Janeiro, in general, aren't ready to serve visually impaired people.

Regarding the interviews conducted with restaurants' staff, the most relevant limitation is the presence of partial truths in the answers due to attempts to give more socially accepted responses. Observation, employed in an effort to diminish this effect, has its limitations as well, including the beholder's personal bias. Besides, informed impressions are also subjective (Cervo \& Bervian, 2006).

\section{RESULTS}

\section{Part 1: Focus groups}

During the analysis of the focus groups discussions, before trying to identify restaurant attributes valued by the visually impaired, it was possible to detect that these people are used to attend restaurants during leisure outings, supporting the idea that the visually impaired are potential customers for this kind of establishment.

- Restaurants are probably our greatest leisure option. 
- Since going anywhere is difficult, restaurants are a good leisure option.

- My blind friends and I go to restaurants a lot when we want to gather and talk.

Literature review indicates that customer loyalty to restaurants is linked to good customer relationship (Salazar, Farias, \& Lucian 2009). For the visually impaired, a good customer relationship involves the restaurant's preoccupation with accessibility.

- For us \{visually impaired\}, it is difficult to find a really accessible restaurant. When we find one, we keep coming back.

- We, visually impaired people, already know that, for example in \{restaurant\} GU, we will be well served. Waiters there are good. So we keep going.

\section{Selecting what to eat: is there a menu in Braille?}

According to law 3.879, enacted in July 2002, restaurants, hotels, snack-bars, and bars located in the city of Rio de Janeiro have to offer menus in Braille. Focus groups participants pointed to the importance of the adoption of menus in Braille, particularly given the autonomy propitiated by them.

- I love getting to a restaurant and being able to decide for myself what I am going to eat. Without menus in Braille that would be impossible.

- Before menus in Braille, I always ordered the same things. Now I can diversify.

- Menu in Braille are awesome! It's autonomy! But not every restaurant has it.

However, many complaints surround menus in Braille, usually due to the absence of prices. Such issues cause visually impaired people to put aside their autonomies and ask waiters to read them the available options, increasing the necessity for personnel training, as pointed out by previous studies (Hogg, \& Wilson 2004).

- You know McDonalds? Have you seen their menu in Braille? On the wall! Do I look like a gecko?
- Braille menus usually do not have prices. I don't want to choose a meal and then have to ask if it will cost me 10 or 100 bucks.

- Opening a big menu is awkward. It troubles everybody, particularly during leisure outings. Braille menus are huge.

Analyzing the testimonies it is possible to realize that the absence of the menu has for the visually impaired the meaning of excuse. The lack of autonomy caused by the lack of the Braille menu is a veto of the perma- nence of these people in restaurants.

\section{Is there anyone here who knows how to serve me?}

Babin et al. (2005) point out service as being an important barrier to the consumption of leisure services. During this study, issues born from service inadequacies occurred often and could prevent visually impaired people from attending restaurants.

- Service is awful. It's not only because I can't see. It's bad even for those who can. The difference is that, if the service isn't good, I can't go. I depend on the service.

- Service is fundamental. In some places waiters are trained to cheat. I like foreign beer. I go to places, ask for foreign beer and the waiter brings me the cheapest, deliberately trying to deceive me. It's unbearable.

This last comment implies that customer deceiving practices seem to take place in some establishments in Rio. Besides this posture, lack of training on how to adequately serve visually impaired people is an issue constantly present in the literature (Hogg \& Wilson 2004; Kaufman 1995). Training has been singled as the main solution for the problems preventing visually impaired people from attending restaurants.

- Training is lacking. There is no need to adapt anything, just train the waiters. Is that too much to ask?

- Obviously I prefer to attend restaurants whose personnel know how to deal with PWDs. A basic training is enough. 


\section{I hate noise! And why so much light?}

Literature supports that consumers favor restaurants with pleasant ambiences, in which lighting and music are adequate to their preferences (Babin et al. 2005). The focus group discussions showed that visually impaired people are likewise affected by ambience.

-The best is when the ambience is good. The food doesn't matter so much.

- If the ambience is really good I don't want to leave.

Low lighting appears as a crucial characteristic for an ambience to be considered pleasant. Bright lights disturb visually impaired people who are sensitive to lights. It's important to point that previous studies show the importance of lighting for retailing ambiences (Carvalho, \& Motta 2004).

- I notice when the ambience is too bright. That really bothers me.

- Too bright a restaurant really bothers me, I can't stay.

- The ideal is for the restaurant to have low lighting. I feel better that way.

Participants informed that they preferred ambiences with low music. Excess of sound or noises tends to impair or prevent communication between visually impaired people.

- When I go to restaurants with my friends I want to talk, with loud music that is difficult.

- To us loud music is terrible because when a group of visually impaired people is talking we don't have visual contact, only sound.

\section{Beware of sharp table edges}

Focus groups participants indicated an attribute that hadn't been previously highlighted in literature: table shape. Tables with central legs and sharp edges were said to be responsible for many accidents involving visually impaired people.

- Do you want to kill a visually impaired person? Place tables with sharp edges.
- When the table legs are inside, what I find first are its edges. Too late to do anything. I am already hurt.

- Once I was walking into a restaurant (...) using my walking stick, but the table had the legs on the inside. So, when I noticed, I was already impaled on its tip. The waiter then said: "Oh, you didn't see the table? I've said many times theses tables shouldn't be of glass." Really (...) I get hurt and have to listen to this kind of stuff.

All subjects shared the same degree of dissatisfaction regarding sharp corners, tips, and central legs. On the other hand, a table's ideal shape was not unanimous: some said rectangular is better because with them it's easier to know where plates, glasses and even other people are; while others, particularly people who were born blind, prefer round tables because it's easier for big groups to communicate around one.

- Rectangular tables are great. They must have rounded corners, obviously. It's easier to locate where things are.

- In a rectangular table I know better where each of my friends is. It's better for talking.

-I know rectangular tables have advantages, but when I go to a restaurant with friends the most important thing is the conversation, and round tables are better for that.

-Seating at a round table is good because everybody is closer.

\section{Excuse me, waiter! Could you come here? \\ Waiter...}

A recurrent complaint was the difficulty in getting waiters' attention. Many subjects resent the embarrassment involved in attracting waiters' attention without knowing where they are.

- Its embarrassing: when I want to order, I must stand up.

- Sometimes I start calling for the waiter and find that he was in the kitchen. He would never listen. It makes me look impolite.

- I holler. I must, but is terrible... everybody stares at you.

To minimize this issue, participants suggested the use of a server paging system: a 
waiter is called if the customer presses a button on the table. However, subjects haven't witnessed such a system implemented in Brazilian restaurants.

- It had to have a button we could press to call the waiter.

- People always think about complex, expensive solutions. All we need is a simple solution. A simple button. A sound signal.

It is important to note that the service is greatly hampered by the difficulties of accessing the waiter. Problems with the service are very detrimental to the evaluation of a restaurant (Tse, Sin, \& Yin 2002; Babin, Lee, Kim, \& Griffim, 2005).

\section{I want autonomy when using the restroom!}

Lack of signs pointing to restrooms is a major issue. Even though subjects recognize that tactile flooring is hard to deploy, some defend that its presence is fundamental for a restaurant to be considered accessible.

- Restaurants must have at least some indication of how to get to the restrooms.

- To get to the restrooms there must be signs. I don't want to have to call a waiter or friend for help to get to the restroom. The best way is installing a tactile floor.

Besides signaling needs regarding the location of restrooms, subjects pointed out the necessity of further signaling. A plate in Braille indicating if the restrooms are for female or male use, for example, is crucial.

- I have entered the wrong restroom many times. It's an unnecessary discomfiture.

- When someone visually impaired enters an unknown restroom he doesn't know where anything is. Finding toilet paper, for instance, is hell.

- I don't want to go to the restroom with anyone. Any signalization giving me autonomy is welcome.

The quest for autonomy is present throughout the life of the person with disabilities and becomes crucial in the construction of the identity of these persons (Hogg \& Wilson, 2004).

\section{Part 2: Results of observations and interviews at the restaurants}

All the interviewed restaurant staff members stated that it is really rare to have visually impaired people attending to the establishments where they work. This preliminary information indicates that extant barriers might be causing visually impaired people to avoid going out to restaurants. Only at restaurant GU the presence of visually impaired people is frequent, possibly due to its proximity to Benjamin Constant Institute, not because it is particularly accessible.

- I can't remember when I last saw a person with disability here. (Waiter_AR)

- Blind people don't come here. Eating Japanese food is difficult enough, I think they get discouraged. They probably don't even like this kind of food. (Waiter_SH)

The last statement shows some prejudice towards PWDs regarding the skills involved in consuming, and possibly appreciating, Japanese food. Biased opinions are often employed to exempt establishments from their faults, including their lack of accessibility.

\section{Accessible infrastructure}

Regarding table shape, five out of the twelve visited restaurants had both rectangular and round tables. Diversity in table shape is positive for visually impaired people since, according to focus group results, participants saw advantages and disadvantages on both types. Nonetheless, in all visited establishments tables had central legs, which can be deemed inadequate and dangerous for the visually impaired. In addition, nine out of the twelve restaurants had tables with sharp edges, also considered dangerous.

Virtually all analyzed restaurants had a low sound ambience, adequate to the needs of visually impaired people. Regarding lighting, seven restaurants were considered too bright, a possible cause of discomfort to visually impaired people with light sensitivity.

None of the visited establishments had restrooms adapted for visually impaired people. 
Some of the interviewees showed good will and stated being ready to guide the visually impaired to the facilities, but that isn't the ideal solution. Most visually impaired people don't like to be accompanied to the restrooms.

- The restrooms are not adapted, but we take them there. Take the person to the door and, if needed, inside too. When it is a woman, we call the cleaning lady to help. (Waiter_PM)

Two interviewees stated that the establishments where they worked had restrooms adapted for PWDs needs. However, careful observation showed that both establishments presented adaptations exclusively for people with impaired mobility.

- We have an exclusive restroom for impaired people, but just for people in wheelchairs. Adaptations were made to fulfill the needs of elders and mobility impaired people. (Manager_OB)

- Downstairs we have an adapted restroom. For people on wheelchairs. There is a proper restroom downstairs and we take them there. (Waiter_EZ)

Among the twelve visited establishments only one had a menu in Braille, but the interviewee stated that it was never sought by costumers. In another establishment, the waiter informed that once there was a Braille menu, but it wasn't usually sought after so it was discontinued.

- We have a menu in Braille that is four years old, I don't know if it is up to date. In these four years there was only one order made using it. We had it made in São Paulo, it was quite expensive, and we never use it. (Manager_OB)

- Once we had a menu in Braille, but we gave up on it. They $\{$ the visually impaired never asked for it. They prefer to have the menu read for them. (Waiter_GU)

All interviewees, even the most solicitous and interested ones, showed ignorance of the law making menus in Braille mandatory. This fact seems to indicate a lack of official control regarding accessibility issues.
- We don't have \{menus in Braille\} yet, but it's a good idea. (Manager_OL)

- We don't have a menu in Braille, but I am committed to stand next to the table. They'll be well served. (Waiter_RS)

During focus groups, subjects suggested that a server paging system would be a good option to help calling waiters and attendants. Such a device, however, was absent in all of the visited establishments.

- They \{the visually impaired have already alerted us, but the boss hasn't installed a paging system yet. (Waiter_GU)

\section{Service}

During the interviews it was possible to perceive that accessibility issues regarding infrastructure - mainly affecting menus and restrooms - are usually dealt with actions of good will by the restaurant staff.

- We don't have menus in Braille (...) Restrooms aren't adapted (...)One day six blind people came here. The sub manager waited their table; he served only them and no one else. They stayed till late, closed the restaurant. (Waiter_MJ)

- One day I waited a blind couple. I read the menu, gave them my full attention and when they left I took them to the taxi stop. (Waiter_PM)

None of the interviewees stated having received training in order to serve visually impaired people. This instance had already been denounced by focus group participants who affirmed having to rely on the promptitude of waiters.

- We didn't get any training, but we talk it through. (Waiter_CC)

- No problem in bringing blind people here, we are used to them... We read the menu, take them to the restrooms. The secret is treating them with joy, joke with them. Our training was practice. (Waiter_GU)

- I didn't get any training. I figured out myself that I had to read the menu for them. (Waiter_PM) 
A careful observation shows that empathy and commitment alone are not enough to supply accessibility. An indicative of this reality is the fact that many interviewees said they advise visually impaired people to come to restaurants only when accompanied.

- We advise them to come accompanied fby someone who isn't visually impaired\}. It helps, doesn't it? (Waiter_EZ)

- They usually come accompanied \{by someone who isn't visually impaired\}. It's in their best interest to have some autonomy. (Waiter_OL)

Associating the autonomy of the visually impaired to the presence of a companion who is not visually impaired is contrary to the notion of accessibility. By advising visually impaired individuals to attend restaurants only when accompanied by someone who isn't visually impaired, restaurants attempt to transfer their responsibility to provide autonomy inside their establishments to the eventual companions.

\section{CONCLUSIONS}

This study aimed to analyze what are the attributes that visually impaired people value the most when in leisure restaurant outings, while also seeking to evaluate if such attributes could be found in restaurants in the city of Rio de Janeiro. Focus groups participants pointed out critical attributes visually impaired people take into consideration regarding their consumption experience in restaurants: menus in Braille; personnel trained to serve visually impaired people; tables without sharp edges and with legs on its corners; low lighting and low noise ambiences; server paging systems to call waiters and appropriate restroom signalization.

One of the enumerated attributes attracts special attention due to its simplicity and due to the fact that it shows how far the lack of interest in tending to the needs of PWDs goes: visually impaired people stated that attracting the attention of a waiter is one of their greatest issues in restaurant outings, a problem that a simple paging system could solve. Such a system would configure a relatively inexpensive solution, but it wasn't available in any of the visited establishments. If the simplest and cheapest solution isn't employed by restaurants, what can be said about the most complex or expensive ones?

Neglect and lack of interest in comprehending what is really valued by PWDs in restaurant outings seems to reflect that society, and consequently business establishments, does not consider PWDs as potential consumers. This perception describes a scenario where, due to ignorance, incompetence or lack of moral precepts, it's not in the best interest of Rio's restaurants to tend to an undesirable segment. Apparently, the government has also been lacking in its efforts to change this behavior or to control the correct application of current laws on accessibility.

Another issue raised by this study that appears to be related to organizational ignorance towards PWDs is generalization. Assuming that all PWDs are equal in their limitations and needs is a mistake. During this study, a high degree of generalization was noticed; particularly when restaurant staff interviewees stated that their establishments had restrooms adapted for PWDs while, actually, those restrooms were adapted only for mobility impaired people.

Results also show that lack of appropriate personnel training on how to tend to PWDs' needs is a major issue. Such outlook leaves PWDs dependent on a waiter's goodwill. What is a right is then viewed as a concession, as a favor provided by restaurant establishments. Regarding this issue, Wanderley (2008) alerts that the transformation of rights into favors reinforces exclusion.

It seems that no changes will take place until restaurant proprietors and managers start to perceive PWDs as part of society and as customers. Businessmen engaged in an industry of such importance should mind and take responsibility for tending to these people needs without offering excuses for accessibility issues such as: "visually impaired people don't want to come to the restaurant" or "blind people always bring in a companion, they solve all the problems".

One can assume that Brazilian businessmen deliberately ignore this market segment, even though it is comprised of next to 17 million people with severe visual impairments or more than 24 million people if all kinds of impairments are considered. Much more serious is the contempt with the exclusion of the 
disabled citizen. Above and beyond the size and importance of this group of people, there is also the idea that restaurants and other establishments could profit from an eventual preoccupation with accessibility issues. This notion, vastly supported by extant literature, points out that modifications in favor of accessibility also please non impaired consumers, be it due to a more socially responsible corporative image or purely due to functional aspects (Faria, Ferreira, \& Carvalho 2010).

During focus groups, subjects perceived that certain restaurant modifications could provide benefits not only for visually impaired customers, but for consumers in general: "A paging system would be useful for everybody. No one likes to shout for a waiter"; "Sharp table edges are also dangerous for children".

It is important to highlight that the restaurant sector is only one among the many related to entertainment, hospitality and culture. Thus, some of the findings in this study could be applied on public and private organizations in other sectors connected to hospitality as well. With regard to studies on people with visual impairment this research is a starting point on the desires of these consumers. Future research may use the findings of this study to initiate investigations in other contexts.

A possible future research venue inspired by these results revolves in finding alternatives for personnel training so they would be better prepared to tend to PWDs needs. Another possibility is investigating the adaptation of physical spaces for PWD customers, in retailing and services, and its practical deployment. For example, an extension of Kaufman's (1995) and Kaufman-Scarborough's (1998; 1999) research on impaired consumers' mobility in brick-andmortar retailing, this time focusing on other types of impairment, could be suggested.

Regarding basic needs of PWDs as citizens, studies on public management should be developed given the undeniable role of the government in promoting fundamental changes in favor of inclusion, such as initiatives in transportation and education. Sawaia (2008) points out that PWDs' exclusion is a political non-commitment to someone else's suffering. On the other hand, Brazilian business and management academics got used to treating inclusion as a topic belonging to the theme of social responsibility, thus dependent on the goodwill of private organizations desiring to expand market share or improve corporate image.

It should be noted that in this research the concern for the well being of people with disabilities existed since the choice of focus in restaurant, confirmed by them as I sit an important theme until the results are released. The article was only submitted once it was approved by the research participants. The TCR was extremely important for the research theme to find support and relevance in the area of marketing that historically did not focus on people with disabilities.

\section{REFERENCES}

Amaro, L., Meira, S., Camargo, \& Slongo, L. (2008). Em que posso ajudar? O varejo e os portadores de deficiência visual. Revista Negócios e Talentos, 5,5-21.

Babin, B., Lee, E., Kim, M \& Griffim, M. (2005). Modeling consumer satisfaction and word-ofmouth: restaurant patronage in Korea. Journal of Services Marketing, 19(3),133-139.

Baker, S. (2006). Consumer normalcy: Understanding the value of shopping through narratives of consumers with visual impairments. Journal of Retailing, 82(1), 3750.

Holland, C., \& Kaufman-Scarborough, C. (2007). How consumers with disabilities perceive "welcome" in retail servicescapes: a critical incident study. Journal of Services Marketing, 21(3), 160-173.

. Stephens, D. \& Hill, R. (2002). How can retailers enhance accessibility: giving consumers with visual impairments a voice in the marketplace. Journal of Retailing and Consumer Services, 9, 227-239.

Bauer, M. (2002). Análise deconteúdo clássica: uma revisão, in: Pesquisa qualitativa com texto, imagem e som: um manual prático. Petrópolis, RJ: Vozes, 189-217.

Beudaert, A., Özçağlar-Toulouse, N., \& Türe, M. (2015). Becoming sensory disabled: Exploring self-transformation through rites of passage, Journal of Business Research, 69(1), 57-64.

Bill, F., \& Olaison, L. (2009). The indirect approach of semi-focused groups: expanding focus group research through role-playing. Qualitative Research in Organizations and Management, 4(1), 7-26. 
Boddy, C. (2005). A rose by any other name may smell as sweet but "group discussion" is not another name for a "focus group" nor should it be. Qualitative Market Research, 8(3), 248255.

Braithwait, D., \& Thompson, T. (2000). Handbook of communication and people with disability: Research and application. New Jersey, NJ: Lawrence Erlbaum Associates.

ALERJ. Assembléia Legislativa do Estado do Rio de Janeiro. (2005). Acessibilidade Para Todos: Uma Cartilha De Orientação. Rio de Janeiro, RJ: ALERJ. Comissão de Defesa da Pessoa com Deficiência.

Carvalho, J. \& Motta, P. (2004),A Iluminação ambiental vista pelos participantes das interações de serviços. GESTÃO.Org. Revista Eletrônica de Gestão Organizacional, 2, 1-15.

Carvalho-Freitas, M. \& Marques, A. (2010). Formas de ver as pessoas com deficiência: um estudo empírico do construto de concepções de deficiência em situações de trabalho. Revista de Administração da Mackenzie, 11(3), 100129.

Cervo; A., \& Bervian, P. (2006). Metodologia científica. 6th ed. São Paulo: Prentice Hall.

Chang, J., \& Hsieh, A. (2006). Leisure motives of eating out in night markets. Journal of Business Research, 59, 1276-1278.

Chomsky, N. (2002). O lucro ou as pessoas? Neoliberalismo e ordem global. Rio de Janeiro, RJ: Bertrand Brasil.

Creswell, J. (1998). Quality inquiry and research design: choosing among five traditions. Thousand Oaks: Sage.

David, J., Gurgel, V., Antunes, X., \& Kastrup, V. (2009). Cidade acessível: Igualdade e singularidade da deficiência visual. Revista de Psicologia, 21(1), 197-198.

Deschenes, J. (2007). Behind closed doors: Reflecting on the emotional challenges of doing consumer research on painful topics. Advances in Consumer Research, 34(1), 20-21.

Dias, T. \& Pereira, L. (2008). Habilidade de localização e lateralização sonora em deficientes visuais. Revista da Sociedade Brasileira de Fonoaudiologia, 13(4), 352-356.

Faria, M., Casotti, L., \& Carvalho, J. (2016). A decisão de compra de veículos adaptados por consumidores com deficiência motora. Revista de Administração da Unimep, 14, p. 102-131.

Faria, M., Ferreira,D., Carvalho, J. (2010). Portador de deficiência como consumidor de serviços de lazer extra-doméstico. Turismo Visão e Ação, 12(2), 28-47.

, Silva, J., \& Ferreira, J. (2012). The visually impaired and consumption in restaurants.
International Journal of Contemporary Hospitality Management, 24, 3-19.

Gava, R. (2006). A estratégia market-driving de orientação para o mercado: modelo teórico e proposições de pesquisa. In: Anais do ENCONTRO DA ANPAD, 30. Salvador, BA: Anpad.

Griffith, M., \& Gilly, M. (2012). Dibs! Customer territorial behavior. Journal of Service Research, 15(2), 131-149.

Goodrichk, R., \& Ramsey, M. (2012). Are consumers with disabilities receiving the services they need? Journal of Retailing and Consumer Services, 19(1), 88-97.

Grougiou, V. \& Pettigrew, S. (2011). Senior customers' service encounter preferences. Journal of Service Research, 14(4), 475-488.

Helgeson, J. (1994). Receiving and responding to a mail survey: a phenomenological examination. Journal of Marketing Research Society, 36(4),339-347.

Hirschman, E., \& Holbrook, M. (1982). Hedonic consumption: emerging concepts, methods and propositions. Journal of Marketing, 46(3), 92-101.

Hogg, G., \& Wilson, E. (2004). Does he take sugar? The disabled consumer and identity. British Academy of Management Conference Proceedings. St. Andrews, Scotland.

Hunter, S. (2002). Foundations of marketing theory: toward a general theory of marketing. London: Sharpe.

IBGE. Instituto Brasileiro de Geografia e Estatística. Censo Demográfico 2010. Available at: <http://www.ibge.gov.br/home/estatistica/p opulacao/censo2010>, Accessed in: June28th, 2012.

Ipiranga, A. (2010). A cultura da cidade e os seus espaços intermediários: os bares e os restaurantes. Revista de Administração Mackenzie, 11(1), 65-91.

Kaufman, C. (1995). Shop 'til you drop: tales from a physically challenged shopper. Journal of Consumer Marketing, 12(3), 39-55.

Kaufman-Scarborough, C. (1999). Reasonable access for mobility-disabled persons is more than widening the door. Journal of Retailing, 75(4), 479-508.

(1998). Retailers' perceptions of the americans with disabilities act: suggestions for low-cost, high impact accommodations for disabled shoppers. Journal of Consumer Marketing, 15(2), 94-110.

Kivela, J. (1997). Restaurant marketing: selection and segmentation in Hong Kong. International Journal of Contemporary Hospytality Management, 9(3), 116-123. 
Koo, L., Tao, F., \& Yeung, J. (1999). Preferential segmentation of restaurant attributes through conjoint analysis. International Journal of Contemporary Hospitality Management, 11(5), 242-250.

Kuppelwieser, V., Finsterwalder, J. (2016), Transformative service research and service dominant logic: Quo vaditis? Journal of Retailing and Consumer Service, 28, 91-98.

Lages, S., \& Martins, R. (2006). Turismo inclusivo: a importância da capacitação do profissional de turismo para o atendimento ao deficiente auditivo. Estação Científica, 3, 1-17.

Laville, C., \& Dionne, J. (1999). A construção do saber: manual de metodologia da pesquisa em ciências humanas. Porto Alegre: Artmed.

Le Breton, D. (2006). A sociologia do corpo. 4. ed. Petrópolis, RJ: Editora Vozes.

Lukaszewski, K. \& Stone, D. (2012). Theory and research on social issues in organizations. Journal of Managerial Psychology, 27(4), 324329.

Mick, D. (2006). Meaning and mattering through transformative consumer research. Advances in Consumer Research, 33(1), 1-4.

Moschis, G., Curasi, C. \& Bellenger, D. (2003). Restaurant-selection preferences of mature consumers. Cornell Hotel and Restaurant Administration Quarterly, 44.

Ozanne, J. (2011). Transformative consumer research: Creating dialogical spaces for policy and action research. Journal of Public Policy \& Marketing, 30(1), 1-6.

. \& Deschenes, J. (2007). Workbench issues in transformative consumer research. Advances in Consumer Research, 34(1), 20-24.

Saatcioglu, B., \& Corus, C. (2007). Participatory action research as engaged practice: Implications for transformative consumer research. Advances in Consumer Research, 34(1), 21-22.

Patton, M. (2002). Qualitative evaluation and research methods. Thousand Oaks: Sage.

Pedraja, M. \& Yagüe, J. (2001). What information do costumers use when choosing a restaurant. International Journal Contemporary Hospitality Management, 13(6), 316-318.

Pereira, C., Toledo, G., \& Toledo, L. (2009). Considerações sobre o conceito de marketing: teoria e prática gerencial. Organizações \& Sociedade, 16(50), 519-543.

Pohl, E., Bollini, L., \& Fajardo , J. (2009). Color \& restaurant design. Barcelona: ReditarLibros.

Popper, K. (2006). Em busca de um mundo melhor. São Paulo: Martins Fontes.

Poria, Y., Reichel, A., \& Brandt, Y. (2011). Dimensions of hotel experience of people with disabilities: an exploratory study. International Journal of
Contemporary Hospitality Management, 23(5), 571-591.

Poyares, M., \& Goldfeld, M. (2008). Análise comparativa da brincadeira simbólica de crianças cegas congênitas e de visão normal. Revista Benjamin Constant, 40, 8-15.

Prideaux, S., \& Roulstone, A. (2009). Good practice for providing disabled people with reasonable access to the built environment. A comparative study of legislative provision. International Journal of Law in the Built Environment, 1(1), 59-81.

Prince, M. \& Davies, M. (2001). Moderator teams: an extension to focus group methodology. Qualitative Market Research, 4(4), 207-216.

Ruddell, J., \& Shinew, K. (2006). The socialization process for women with physical disabilities: the impact of agents and agencies in the introduction to an elite sport. Journal of Leisure Research, 38(3), 421-444.

Ryu, K., Han, H., \& Jang, S. (2010). Relationships among hedonic and utilitarian values, satisfaction and behavioral intentions in the fast-casual restaurant industry. Emerald Emerging Markets Case Studies, 22.

Salazar, S., Farias, S. \& Lucian, R. (2009). O papel das pessoas nos ambientes de restaurantes gastronômicos e a satisfação do cliente. Turismo. Visão e Ação, 11, 325-340.

Sampieri, R., Collado, C., \& Lucio, P. (2006). Metodologia de pesquisa. 3rd ed. São Paulo, SP: McGraw-Hill.

Sansivieiro, S. \& Dias, C. (2005). Hotelaria e acessibilidade. Turismo Visão e Ação, 7(3), 439-453.

Sassaki, R. (2003). Inclusão e no lazer e turismo: em busca da qualidade de vida. São Paulo, SP: Áurea.

Sawaia, B. (2008). Introdução: Exclusão ou inclusão perversa? In: As Artimanhas da Exclusão: Análise Psicossocial e Ética da Desigualdade Social. Sawaia, B (Org.), 8th ed. Petrópolis, RJ: Editora Vozes.

Shi, L., Cole, S., \& Chancellor, H. (2012). Understanding leisure travel motivations of travelers with acquired mobility impairments. Tourism Management, 33(1), 228-231.

Stokes, D., \& Bergin, R. (2006). Methodology or "methodolatry"? An evaluation of focus groups and depth interviews. Qualitative Market Research, 9(1), 26-37.

Thompson, G. (2011). Cherry-picking customers by party size in restaurants. Journal of Service Research, 4(2), 201-213.

Toma, J. (2000). How to getting closer to your subjects makes qualitative data better. Theory Into Practice, 39(3), 177-183. 
Tse, A., Sin, J., \& Yin, F. (2002). How a crowded restaurant affects consumers' attribution behavior. International Journal of Hospitality Management, 21(4), 449-454.

Turmusani, M. (2004). An eclectic approach to disability research: a majority world perspective. Asia Pacific Disability Rehabilitation Journal, 15(1), 3-11.

Van Harten, W., Veldhuis, M., Hoeksma, B., \& Krabbendam, K. (2007). Strategic behaviour of institutional providers in mental handicapped care in The Netherlands. Journal of Health Organization and Management, 21(2), 184193.
Wanderley, M. (2008). Refletindo sobre a noção de exclusão. In: As artimanhas da exclusão: Análise psicossocial e ética da desigualdade social. Sawaia, B. (Org.). 8th Ed. Petrópolis, RJ: Editora Vozes.

White, G. (2002). Consumer participation in disability research: The golden rule as guide for ethical price. Rehabilitation Psychology, 47(4), 438-446.

Woodliffe, L. (2004). Rethinking consumer disadvantage: The importance of qualitative research. International Journal of Retail \& Distribution Management, 32(11), 523-531.

Yin, R. (2005). Estudo de caso: Planejamento e métodos. 3rd ed. Porto Alegre, RS:Bookman. 